\title{
量子ポイントコンタクトから出射された 電子波の角度分布
}

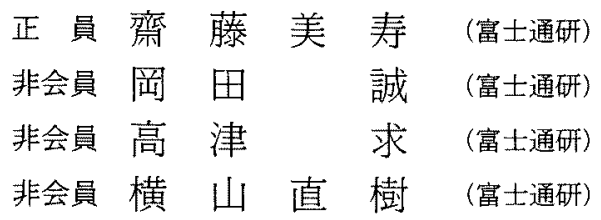

\section{Angular Distribution of Electron Waves Injected through a Quantum Point Contact - Measurement and Analysis}

\section{Miyoshi Saito, Member, Makoto Okada, Non-member, Motomu Takatsu, Non-member, Naoki} Yokoyama, Non-member (Fujitsu Laboratories Limited)

We have measured the transfer efficiency of electrons from one Quantum Point Contact (QPC) to another QPC as a function of magnetic field. We obtained a double-peak profile for the point contact quantized to two wave modes. We suggested that this profile reflects the angular distribution of electrons emitted from the QPC using Fraunhofer diffraction approximation through the QPC by an electron propagating according to Green's function. However we used classical Lorentz force for analysis to account for the effect of the magnetic field. The analysis seems to be an unnatural mixture of quantum mechanics and classical mechanics. This paper describes quantum mechanical Fraunhofer diffraction analysis including the magnetic field to resolve this unnaturalness. This analytic result agreed with the above analytic and experimental results, confirming that we have measured angular distribution of electron wave injected through a QPC. It should be noted that our double-peak profile is explained by Fraunhofer diffraction of electron wave. This paper also discusses the interference between the 1st and 2 nd mode electron waves.

キーワード：量子ポイントコンタクト。電子波, フラウンホーファー回折, コンダクタンスの量子化, 出射角分布，異モード間干渉，境界，弱磁界中のグリーン関数

\section{1.まえがき}

半導体微細加工技術の進歩に伴い, 樣々な量子効果 を人工的に出現させることが可能となってきた。コン

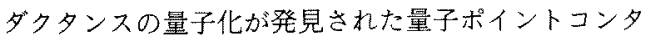
クトもその一つである(1)(2)。これらの量子効果は構造 の大きさをド・ブロイ波長程度にしたときに現れる電 子の量子力学的波動性によるものである。現在, 量子 ポイントコンタクトなど微細構造中（メソスコピック 領域）を電子が伝導するモデルとして，ビリヤードモ デル(3)やプロパダーティングウェーブの考え方がある
が，粒子的なビリヤードモデルだけで様々な現象を説 明できるのかは不明である。本来，波動性と粒子性を 明確に分けることはできないが，著者らは電子の波動 的側面老積極的沉考慮すべきであると考えている。ま たホポイントコンタクトを出た後の電子の様子も波動 的な振舞いを示すのか，粒子的な振舞いを示すのかを 知ることは量子ポイントコンタクトのデバイス応用を 考えるうえでも重要である。

本論文では量子ポイントコンタクトから出射された 電子の角度分布の磁界を利用しての測定と, その結果 の解釉について述べる(4)。更に, 境界条件扔よび磁界 
の効果に関して文献 $(4)$ 上り正確に取扱った解析につ いて述へ，また異なるモード間の干涉の有無について も考察する。

\section{2. 量子ポイントコンタクトから出射された 電子の角度分布 ${ }^{(4)}$}

ポイントコンタクトから出射された電子の角度分布 を磁界の関数として測定した実験について述べる。

$\langle 2 \cdot 1\rangle$ 電子波分布の測定素子について 図 1 に 示す素子を用いて測定を行った。ポイントコンタタト をシリーズに接続し，エミッタ側のポイントコンタタ トをインジェクタ、コレクタ側をディテクタとして用 いる。ポイントコンタクトは GaAs/AlGaAs 変調ド 一ブ構造上に電子線露光法を用いて描画したショット キースプリットダートを用いて形成した。使用した HEMTエピ結晶に扔ける二次元電子ガス（2 DEG） の, $1.2 \mathrm{~K}$ に扝ける移動度 $\mu$ は $3 \times 10^{5} \mathrm{~cm}^{2} / \mathrm{V} \cdot \mathrm{s}, N_{s}$ は $3.5 \times 10^{11} \mathrm{~cm}^{-2}$ であった。これらから見積もられ る平均自由行程は $2.9 \mu \mathrm{m}$ で二つのポイントコンタク 卜間の距離 $1 \mu \mathrm{m}$ より長い。また, 見積もられたフェ ルミ波長は $42 \mathrm{~nm}$ である。

平均自由行程 $L_{e}$ 流

$$
\begin{gathered}
L_{e}=\frac{\hbar \mu}{e} \sqrt{2 \pi N_{s}} \\
\text { また, フ土ルミ波長 } \lambda_{F} \text { は } \\
\lambda_{F}=\sqrt{2 \pi / N_{s}}
\end{gathered}
$$

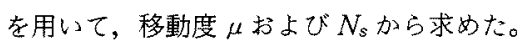

$\langle 2 \cdot 2\rangle$ 実験方法 ${ }^{(3)(4)}$ 図 2 に測定系を示す。コ レクタ、ベースを各々接地し，エミッターコレクタ間 に $\mathrm{AC}$ 電圧㧍よび $\mathrm{DC}$ オセット電圧を数 $+\mu \mathrm{V}$ オー

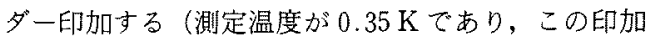
電圧による電子のヒーティングが問題にならない測定 である。すなわち $V<k T / e)$ 。このとき印加電圧の 逆転を避けるためにオフセット電圧を印加している。

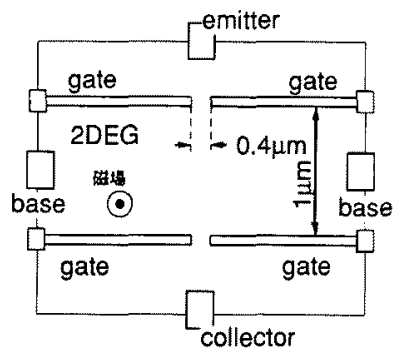

図 1 電子波分布測定素子

Fig. 1. A schematic top view of the device.
コレクタ側のアースの前段にロックインアンプを接続 し, エミッ夕電流を振動させ, 電流感度モードで $\alpha=d\left(I_{C}\right) / d\left(I_{E}\right)$ (コレクタ到達率) を測定する。

まず,エミッタ側のポイントコンタクトによるコン ダクタンスの量子化を確認した。測定結果を図 3 に示

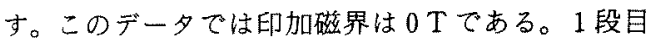
がモード（チャネル orサブバンド）数 1 個に対応し， 2 段目がモード数 2 個に対応する。この測定は，イン ジェクタとして用いるポイントコンタクトに印加する ゲート電圧とモード数の関係を調べる目的で行った。 ゲート電圧 $-0.28 \mathrm{~V}$ 付近がモード数 1 個, $-0.195 \mathrm{~V}$ 付近がモード数 2 個となった。同様にコレクタ側のコ ンダクタンスの量子化も確認した。

次に，印加する磁界を掃引することによりエミッタ 側のポイントコンタクトから出射した電子の角度分布 を测定する。磁界は 2 DEGに対して図1に示すよう に垂直に印加する。このときコレタタ側のポイントコ ンタタトをディテクタとして使用する。このディテク タを通過した電子のみコレクタに到達し検出され，そ の他の電子はべース電流となる。その結果エミッ夕か らコレクタへの到達率が測定される。0Tのときには 直進する電子のみ検出される。磁界印加時には, 電子 はローレンッカによる円弧軌道を描き，その軌道に対

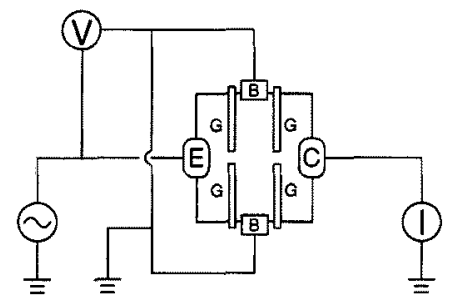

図 2 測定系

Fig. 2. Measurement system.

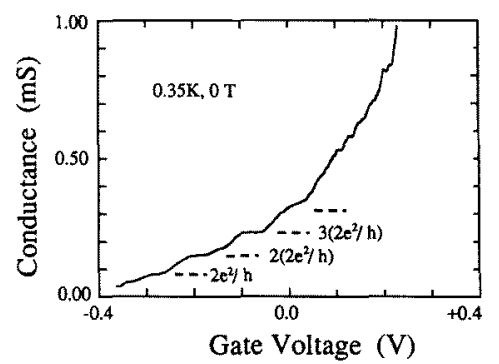

図 3 エミッタ側のポイントコンタクトによる コンダクタンスの量子化

Fig. 3. Quantized conductance of the emitter quantum point contact.

T. IEE Japan, Vol. 110-C, No. 12, '90 


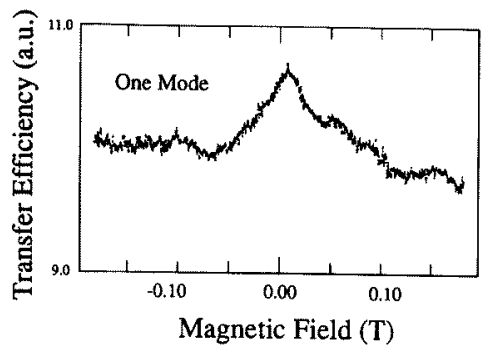

図 4 モード数が1のときの測定結果

Fig. 4. Experimental result for the QPC having one mode.

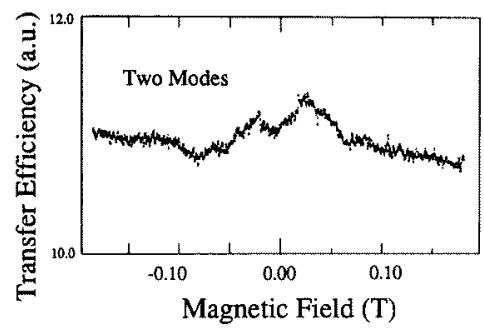

図 5 モード数が2のときの測定結果

Fig. 5. Experimental result for the QPC having two modes.

応する角度に出射した電子のみが検出される（図 9 参 照)。従って，磁界を掃引することによりポイントコ ンタタトから出射された電子の角度分布走磁界の関数 として測定できる。

モード数と電子の角度分布の関係を調べるために, 上記の測定をエミッタ側ポイントコンタタトでのモー

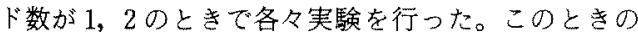
ゲート電压峈各々 $-0.28 \mathrm{~V},-0.195 \mathrm{~V} に$ 固定し，コ レクタ側のポイントコンタクトについてはモード数三 つ分に相当する電圧を印加した。

〈2・3〉測定結果 ポイントコンタクトでのモー ド数が1（基底サブバンドのみ）のときの結果を図 4 に，モード数が 2 のをきの結果を図 5 に各々示す。図 4, 図 5 に示すように, モード数 1 のときには中心に 一つの大きなピークがある分布が得られ，モード数 2 のときには中心はくぼみ中心からずれたところに対称 的なダブルピークが得られ，モード数の違いによる分 布の相違を見いだした。また，実験における印加磁界 はー0.18 T〜+0.18 Tであり，この範囲で上記ゲー 卜電圧に扔いてポイントコンタクトでのモード数の変 化 $^{(5)}$ が生じてないことを確認している。以上の測定は $0.35 \mathrm{~K}$ で行った。

\section{3. 実験結果の解析}

著者らは，この実験結果に対して電子波の伝搬とい う立場で解析を行った。

インジェクターディテクタ間の距囄 $(1 \mu \mathrm{m})$ は平均 自由行程 $(2.9 \mu \mathrm{m})$ より短いので，解析すべてにわた る要請として,この距離のレンジで電子は散乱を受け ないとした。従って，電子はこの間を位相情報を保っ た電子波として伝搬する。

また，ポイントコンタクト内での電子の伝搬につい ては以下のように考えられる。ポイントコンタクトの 入口から入射した電子波は，横方向の閉込如上って 生じたサブバンド（またはモード）に分解され，ポイ ントコンタタト内を量子化された電子波（定在波的分 布をもつ電子波）として伝搬し出口まで到達する。

〈3・1〉節では, ポイントコンタタトの出口から出射 した量子化された電子波が，ディテクタの位置に置い たスクリーンまでグリーン関数によって伝搬し，その 電子強度が投影されるというモゴルで計算を行った。 すなわち，印加殕界零のときの投影像である。

また，実際にディテタタとして検出に用いたのは点 状のポイントコンタタトであるので，この投影像が磁 界によるローレンツカで移動したとして，古典的に磁 界の効果を取入れた。

$\langle 3 \cdot 2\rangle$ 節では，ポイントコンタタトの出ロから出射 した電子波について，異なるモード間の干渉の出現の 有無について考察する。

〈3・3〉節で, 磁界の効果を量子力学的に取入れて ポイントコンタクトの出ロからディテクタの1点まで 電子波を伝般させ，同様な計算を行う。従って，この 解析では電子の強度を磁界の関数として直接求めるこ とができる。

$\langle 3 \cdot 1\rangle$ 電子波のフラウンホーファー回折 ${ }^{(4)}$

本節では，電子波によるフラウンホーファー回折の モデルで計算を行う。すな⿰力口，インジェクターディ テクタ間の距離はインジェクタの出口の間隔に比べて 十分に長いという条件である。

出口での電子の波動関数については, 実際の量子ポ イントコンタクトは図6に示すように緩やかに拡がっ ていく形状であり，従ってポイントコンタクトの中心 部での固有波動関数が断熱的に広がっていくと考えら れる。そこで，桩がった固有波動関数が出口から出射 さ机るとして計算を行った。また, 以下の計算に扔い てはポイントコンタクトによるポテンシャルの形状を 簡単のため井戸形とする。また，今回の測定温度は $0.35 \mathrm{~K}$ と十分低いので, 電子はフェルミエネルギー

電学論C, 110 巻 12 号, 平成 2 年 


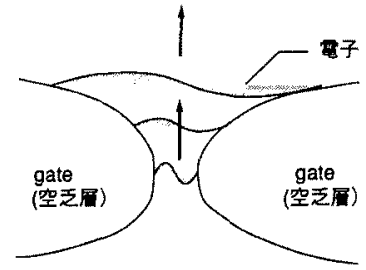

図 6 ポイントコンタクト中を伝搬する波動 関数が断熱的に搪がっていく様子

Fig. 6. Adiabatic propagation of the wave function through a $Q P C$, showing the broadening of the wavelength.

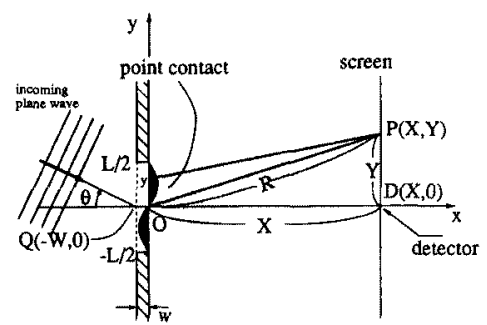

図 7 計算で用いた系

Fig. 7. The system we used for our calcu. lation.

で伝搬するとする。

計算は図 7 に示す座標で行った。ゲートに沿った万 向をy方向，ポイントコンタタト中での電子の進行 方向を $x$ 方向とし，ポイントコンタタトの出口の中 心を原点 $O$,ポイントコンタクトからスタリーンまで の距離を $X$, スクリーン上の点を $P(X, Y)$ とする。 また， $\overline{\mathrm{OP}}=\mathrm{R}$ ポイントコンタクトの輻 ( $y$ 方向) を $L$, 長さ $(x$ 方向 $)$ を $W$ とする。

ポイントコンタタトの出ロでの波動関数はポイント コンタクト内でのモード数が1のときは，

$$
\begin{array}{r}
\Omega_{1}(0, y)=\sqrt{2 / L} e^{i k_{x} W} \cos (\pi y / L) \\
(-L / 2 \leq y \leq L / 2) \cdots \ldots \ldots \ldots \ldots . . .
\end{array}
$$

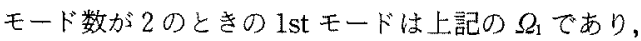
2 nd モードは,

$$
\begin{array}{r}
\Omega_{2}(0, y)=\sqrt{2 / L} e^{i k^{\prime} w} \sin (2 \pi y / L) \\
(-L / 2 \leq y \leq L / 2) \ldots \ldots \ldots \ldots \ldots . .
\end{array}
$$

ここで $k_{x}, k_{x}^{\prime}$ は各々

$$
k_{x}=\sqrt{k_{F}^{2}-\left(\frac{\pi}{L}\right)^{2}}, k_{x}^{\prime}=\sqrt{k_{F}^{2}-\left(\frac{2 \pi}{L}\right)^{2}}
$$

である。また，出口を除いた部分のゲートによる境界 $(x=0)$ 上に拈いては，

$$
\Omega(0, y)=0 \quad(y \leq-L / 2, L / 2 \leq y)
$$

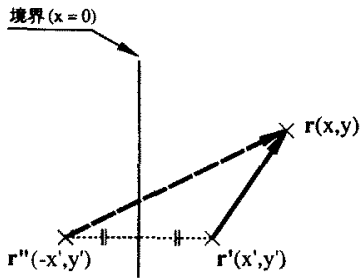

図 8（8)式を満たすグリーン関数を求める ための鏡像法を示す図

Fig. 8. Method of images to obtain the Green's function.

とし，出口以外のゲート上には電子が存在しないとい う境界条件をとる。すなわち，上記の（1），(2)， (4) 式は境界 $x=0$ 上で波動関数 $\Omega$ を气ている。

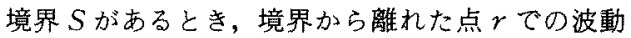
関数はグリーン閔数を用いて

$$
\begin{aligned}
\Psi(\vec{r})= & -\frac{\hbar}{2 m^{*}} \int_{S} d \vec{S}^{\prime}\left\{G\left(\vec{r}, \vec{r}^{\prime}\right) \vec{D}^{\prime} \Psi\left(\vec{r}^{\prime}\right)\right. \\
& \left.-\Psi^{\prime}\left(\vec{r}^{\prime}\right) \vec{D} \cdot G\left(\vec{r}, \vec{r}^{\prime}\right)\right\}
\end{aligned}
$$

の表式で表される*!。

特に，今の場合には境界上での波動関数を与える Diriclet 問題になるので，境界上で

$$
G\left(\vec{r}, \vec{r}^{\prime}\right)=0 \quad\left(r^{\prime}: S \text { 上 }\right)
$$

を満たすグリーン関数を使う（以後ここの条件を満た すグリーン関数を $G^{D}$ と書く〉。従って $(5)$ 式は，

$$
\Psi(r)=\frac{\hbar}{2 m^{*}} \int_{s} d \overrightarrow{S^{\prime}} \Psi\left(\vec{r}^{\prime}\right) \vec{D}^{\prime} G^{D}\left(\vec{r}, \overrightarrow{r^{\prime}}\right)
$$

となる。

いま，境界は $x=0$ 上にあるので $G^{D}$ は，二次元自 由粒子グリーン関数,

$$
\begin{aligned}
& G^{0}\left(x, y ; x^{\prime}, y^{\prime}\right) \\
& \quad=-\frac{m^{*}}{\pi \hbar} K_{0}\left(-i k_{F} \sqrt{\left(x-x^{\prime}\right)^{2}+\left(y-y^{\prime}\right)^{2}}\right)
\end{aligned}
$$

を用いると, 図 8 に示す通常の鏡像法により(6)式を 満たすグりーン関数が求められ以下のと抢りになる。

$$
\begin{aligned}
& G^{D}\left(x, y ; x^{\prime}, y^{\prime}\right) \\
& =-\frac{m^{*}}{\pi \hbar}\left[K_{0}\left(-i k_{F} \sqrt{\left(x-x^{\prime}\right)^{2}+\left(y-y^{\prime}\right)^{2}}\right)\right. \\
& \left.\quad-K_{0}\left(-i k_{F} \sqrt{\left(x+x^{\prime}\right)^{2}+\left(y-y^{\prime}\right)^{2}}\right)\right]
\end{aligned}
$$

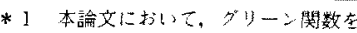
$(E-H) G(\vec{r}, \vec{r})=\hbar \delta(\vec{r}-\vec{r})$ て些转する。
} 


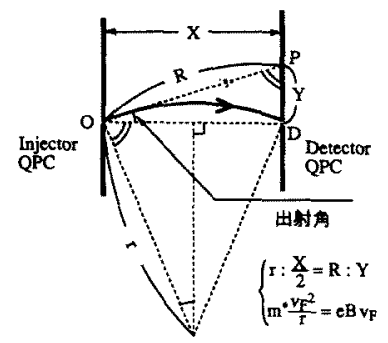

図 9 出射角之軌道半径の関係

Fig. 9. Relation among orbital radius and injection angle of electrons.

(1)，（2）式の波動関数を(7)式の表式により $G^{D}$ ((9)式]でポイントコンタクトから点 $P(X, Y)$ まで 伝搬させる。その結果, 点 $P$ ての電子の強度はモー ド数が1のときには(ただし $R \gg L, k_{F} R \gg 1 の$ 条件で 展開),

$$
\begin{aligned}
\left|\Psi_{1}(X, Y)\right|^{2}= & \frac{k_{F} L}{4 \pi} \frac{X^{2}}{R^{3}}\left\{\frac{\sin \left(\frac{\pi}{2}-\frac{k_{F} L Y}{2 R}\right)}{\frac{\pi}{2}-\frac{k_{F} L Y}{2 R}}\right. \\
& \left.+\frac{\sin \left(\frac{\pi}{2}+\frac{k_{F} L Y}{2 R}\right)}{\frac{\pi}{2}+\frac{k_{F} L Y}{2 R}}\right\}^{2} \cdots(10)
\end{aligned}
$$

モード数が 2 のきには 1 st モードと 2 nd モードの 干涉項注消えて

$|\Psi(X, Y)|^{2}$

$$
\begin{aligned}
= & \left|\Psi_{1}(X, Y)\right|^{2}+\left|\Psi_{2}(X, Y)\right|^{2} \\
= & \left|\Psi_{1}(X, Y)\right|^{2}+\frac{k_{F} L}{4 \pi} \frac{X^{2}}{R^{3}}\left\{\frac{\sin \left(\pi-\frac{k_{F} L Y}{2 R}\right)}{\pi-\frac{k_{F} L Y}{2 R}}\right. \\
& \left.-\frac{\sin \left(\pi+\frac{k_{F} L Y}{2 R}\right)}{\pi+\frac{k_{F} L Y}{2 R}}\right\} \cdots \cdots \cdots \cdots \cdots(11)
\end{aligned}
$$

となる*2。

これらは, 印加磁界がないときにディテクタの位置 に置いたスクリーンに投影される回折像である。この 回折像を磁界心掃引によって測定したと考えられる。 そこで，印加磁界が微弱なので，電子は古典的な円弧 軌道を通るとする。図 9 に示すように出射角と軌道半 径の幾何学的な関係から，(10)，(11)式は各々以下の ようになる。モード数1のとき，

*2ここで, 1 st

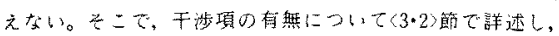
(11)式の結果が正しい二と寺す。

電学論C, 110 巻 12 号, 平成 2 年

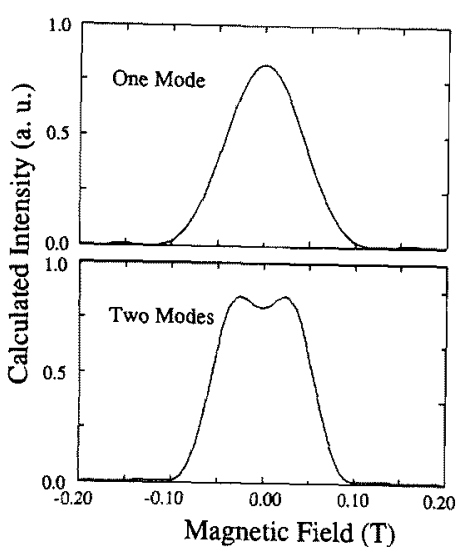

図 10 フラウンホーファー回折の近似を 電子波に適用した計算結果

Fig. 10. Calculation.

$$
\begin{aligned}
& \left|\Psi_{1}(X, B)^{2}\right|=\frac{k_{F} L}{4 \pi} \frac{X^{2}}{R^{3}}\left\{\frac{\sin \left(\frac{\pi}{2}-\frac{e B L X}{4 \hbar}\right)}{\frac{\pi}{2}-\frac{e B L X}{4 \hbar}}\right. \\
& \left.+\frac{\sin \left(\frac{\pi}{2}+\frac{e B L X}{4 \hbar}\right)}{\frac{\pi}{2}+\frac{e B L X}{4 \hbar}}\right\}^{2} \\
& =\left|\Psi_{1}(X, B)\right|^{2}+\frac{k_{F} L}{4 \pi} \frac{X^{2}}{R^{3}} \\
& \times\left\{\frac{\sin \left(\pi-\frac{e B L X}{4 \hbar}\right)}{\pi-\frac{e B L X}{4 \hbar}}-\frac{\sin \left(\pi+\frac{e B L X}{4 \hbar}\right)}{\pi+\frac{e B L X}{4 \hbar}}\right\}^{2}
\end{aligned}
$$

これらをプロットしたものを図10亿示す。上段が

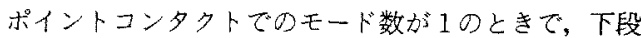
がポイントコンタクトでのモード数が 2 のをざあ

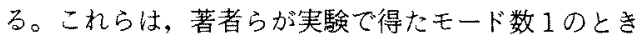
のシングルピーク，モード数 2 とをのダブルピーク と形状が一致し，特にモード数が 2 個のときのポイン トコンタクトの出口に打りる夷効的な幅を $150 \mathrm{~nm}$ と すると、ダブルピークの位置は実験データと一致す る。また，モード数１個のときの出口に抢ける実効的 な幅を $90 \mathrm{~nm}$ とした。

$2 \mathrm{DEG} フ ェ ル ミ$ 波長 $42 \mathrm{~nm}$ 加見積もられる， モード数10ときのポイントコンタクトの幅 $21 〜$ $42 \mathrm{~nm}$, モード数 2 のときの゙イントコンタタトの楅 
42〜63 $\mathrm{nm}$ に比べて出口のフィティングした実効的な 幅が大きい。しかし，これは微細加工部分の $N_{s}$ が薄 くなっていることおおび出口の形状が緩やかに拡が っていくことによるポイントコンタクトの出ロでの波 動関数の広がりのためと考えれば説明がつく（図 6)。

\section{〈3.2〉入射波の対称性とモード間の干涉}

ポイントコンタクトを通過してきた電子波は各モー ドに分解されているが，もともと一つの電子であり， ポイントコンタクト出射後, 異モード間の干涉効果が 生ずると考えられる。ここでは，1 stモードと2 nd モードについての干涉効果について考察する。

まずホホイントコンタクトの入口から平面波をポイ ントコンタクト内に入射させる。図7に示すようにポ イントコンタクトに対し，もの角度で入射する平面波 は次式となる。ここで $Q(-W, 0)$ をポイントコンタ クトの入ロの中心とする。

$$
\Phi_{s}(x, y)=e^{i k_{f} y \sin 9} e^{i k_{r}(x+W) \cos 9 .}
$$

ポイントコンタクト中で電子の波動関数は $x$ 方向と $y$ 方向が分離可能で, モード数 2 個のときは,

$$
\begin{aligned}
\Omega_{\theta}(x, y)= & \alpha(\vartheta) \chi_{1}(y) e^{i k x(x+W)} \\
& +\beta(\vartheta) \chi_{2}(y) e^{i k^{\prime} x(x+W)}
\end{aligned}
$$

と表される。ここで， $\chi_{1}(y)$ は $y$ 方向についての一番 下の準位の固有関数であり，ポイントコンタクト内の 系が y方向に関して対称という条件の下で偶関数て ある。 $\chi_{2}(y)$ は 2 番目の準位の固有関数で系が対称で あるなら奇関数である。また， $\alpha(\theta), \beta(\theta)$ は $\theta$ に依 存する展開倸数である。

$y$ 方向についての全系の詨称性加ら入射波の波動関 数は次の対称性を有する（ただし，磁界がないとき）。

$$
\Phi_{9}(x, y)=\Phi_{-s}(x,-y)
$$

従ってポイントコンタタト中での波動関数も同じ対称 性を有し,

$$
\Omega_{\vartheta}(x, y)=\Omega_{\rightarrow}(x,-y)
$$

(15)，(17) 式より， $\alpha, \beta$ は次の対称性を有する,

$$
\alpha(\theta)=\alpha(-\vartheta), \quad \beta(\vartheta)=-\beta(-\vartheta) \cdots \cdots(18)
$$

(15)式で表記される波動関数がポイントコンタクトの 出口まで伝搬したとき，出口での波動関数は，

$$
\Omega_{\vartheta}(0, y)=\alpha(\theta) \chi_{1}(y) e^{i k_{x} W}+\beta(\theta) \chi_{2}(y) e^{i k^{\prime} x W}
$$

となる。これを,グリーン関数 $G て ゙$ 出口からディテ クタまで伭搬させる。ディテタタでの波動関数 $\Psi$ は 形式的に,

$$
\Psi_{\vartheta}=\alpha(\theta) e^{i k x w}\left\{\boldsymbol{G} \chi_{1}(y)\right\}+\beta(\vartheta) e^{i k^{\prime} x w}\left\{\boldsymbol{G} \chi_{2}(y)\right\}
$$

のように書ける。

$$
\begin{aligned}
& \text { このときの強度は, } \\
& \qquad \begin{aligned}
\left|\Psi_{\vartheta}\right|^{2}= & |\alpha(\vartheta)|^{2}\left|\boldsymbol{G} \chi_{1}(y)\right|^{2}+|\beta(\vartheta)|^{2}\left|\boldsymbol{G} \chi_{2}(y)\right| \\
& +\left[\alpha^{*}(\vartheta) \beta(\vartheta) e^{i\left(k^{\prime} x-k_{x}\right) w}\right. \\
& \left.\times\left\{\boldsymbol{G} \chi_{1}(y)\right\}^{*}\left\{\boldsymbol{G} \chi_{2}(y)\right\}+\text { c. c. }\right]
\end{aligned}
\end{aligned}
$$

ここで c. c. : 複菜共役な項

となる。ここで第 3 項，第 4 項は 1 st モート゚と 2 nd モードの干涉項で $\alpha, \beta$ は平面波の入射角 $\theta$ に依存し， $\left(k_{x}^{\prime}-k_{x}\right) W$ は 1 st モードと2nd モードの進行方向 についての波数ベクトルの違いからポイントコンタク 卜内を伝搬することによって生じる位相差である。

入射平面波 $\emptyset$ はすべての方向からポイントコンタ クトに入射するので，実際の測定で検出される強度は $\vartheta$ に関しての平均であり, 以下のものである。

$$
\begin{aligned}
\left\langle\left|\Psi_{\theta}\right|^{2}\right\rangle_{\theta}= & \left\langle|\alpha(\vartheta)|^{2}\right\rangle_{\diamond}\left|\boldsymbol{G} \chi_{1}(y)\right|^{2} \\
& +\left\langle|\beta(\theta)|^{2}\right\rangle_{\theta}\left|\boldsymbol{G} \chi_{2}(y)\right|^{2} \\
& +\left(\left\langle\alpha^{*}(\vartheta) \beta(\vartheta) e^{i\left(k^{\prime} x-k_{x}\right) W}\right\rangle_{\theta}\right. \\
& \left.\times\left\{\boldsymbol{G} \chi_{1}(y)\right\}^{*}\left\{\boldsymbol{G} \chi_{2}(y)\right\}+\text { c. c. }\right\}
\end{aligned}
$$

干涉項について考察する。一-方向からの入射平面 波の伝搬による,ディテクタにおける電子の強度を同 様见求めると，

$$
\begin{aligned}
\left|\Psi_{-\vartheta}\right|^{2}= & |\alpha(-\vartheta)|{ }^{2}\left|\boldsymbol{G} \chi_{1}(y)\right|^{2}+\left.|\beta(-\vartheta)|\right|^{2}\left|\boldsymbol{G} \chi_{2}(y)\right| \\
& +\left[\alpha^{*}(-\vartheta) \beta(-\vartheta) e^{i\left(k^{\prime} x-k \times\right.}\right) W \\
& \left.\times\left\{\boldsymbol{G} \chi_{1}(y)\right\}^{*}\left\{\boldsymbol{G} \chi_{2}(y)\right\}+\text { c. c. }\right] \cdots(23)
\end{aligned}
$$

となる。

$\vartheta$ 方向からの波と一タ方向の波の平均をとると干涉 項は相殺され次のようになる( (18)式を用いる)。

$$
\begin{aligned}
& \frac{\left|\Psi_{\theta}\right|^{2}+\left|\Psi_{-\partial}\right|^{2}}{2} \\
& \quad=|\alpha(\vartheta)|^{2}\left|\boldsymbol{G} \chi_{1}(y)\right|^{2}+|\beta(\vartheta)|{ }^{2}\left|\boldsymbol{G} \chi_{2}(y)\right|^{2}
\end{aligned}
$$

現在の解析法では正確な議論はできないが，コンダク タンスの量子化から 1 st モードと 2 nd モードは同じ 寄与を与えると考元られるので，展開係数についての 平均哇

$$
\left\langle|\alpha(\vartheta)|^{2}\right\rangle_{\vartheta} \approx\left\langle|\beta(\vartheta)|^{2}\right\rangle_{\vartheta}
$$

とする。

従って, 強度の $\theta$ に関する平均は

$$
\left\langle\left|\Psi_{s}\right|^{2}\right\rangle_{\theta} \sim\left|\boldsymbol{G} \chi_{1}(y)\right|^{2}+\left|\boldsymbol{G} \chi_{2}(y)\right|^{2}
$$

となり，系の対称性から印加磁界がないときには1st モードと 2 nd モードの干涉項は相殺され，検出され ない。

従って, 行うべき計算は出口ての波動関数をディテ クタまでグリーン関数で伝搬させ，ディテクタでの 
1 st モードと2ndモードの強度を計算し和をとれば よい。よって，〈3・1〉節のように干涉項が現れないと することは妥当である。

\section{〈3.3〉弱磁界中のグリーン関数による伝搬}

$\langle 3 \cdot 1 〉$ 節の解析において，電子波の伝搬に関しては 量子力学内で考察している。一方，磁界に関してのみ 古典的に取报っており，若干不自然である。そこで， ここでは磁界をも量子力学の範囲内に包含した議論を 行う。従って，電子の円弧状の古典軌道を特には考慮 しない解析となる。

磁界を考慮した場合，グリーン関数が満たすべき方 程式は（スピンを考えない場合），

$$
\begin{aligned}
& {\left[i \frac{\partial}{\partial t}-\frac{1}{\hbar}\left\{\frac{1}{2 m^{*}}(\vec{P}-e \vec{A})^{2}+e \phi\right\}\right] G^{A}\left(\zeta, \zeta^{\prime}\right)} \\
& \quad=\delta^{(4)}\left(\zeta-\zeta^{\prime}\right) \cdots \ldots \ldots \ldots \ldots \ldots \ldots \ldots \ldots \ldots \ldots \ldots \ldots \ldots \ldots \ldots \ldots
\end{aligned}
$$

である。弱磁界中においては，境界がないときのグリ ーン関数は次のように近似できる同(7)*3,

$$
\begin{aligned}
& G^{A}\left(\zeta, \zeta^{\prime}\right)=\exp \left\{i \frac{e}{\hbar} \varphi\left(\zeta, \zeta^{\prime}\right)\right\} G^{0}\left(\zeta, \zeta^{\prime}\right) \\
& こ こ て ゙, G^{0} \text { : 自由粒子グリーン関数 }
\end{aligned}
$$

また, $\varphi$ は

$$
\varphi\left(\zeta, \zeta^{\prime}\right)=\sum_{\mu=0}^{3} \int_{5^{\prime}}^{\zeta} d \xi^{\mu} A_{\mu}(\xi)
$$

で線積分はら゙かららまでの直線上で実行する。らお よびAは四次元べクトルであり，次に示すもので ある。

$$
\begin{aligned}
& \zeta^{\mu}=(t, x, y, z) \\
& \left.A^{\mu}=\left(\phi, A_{x}, A_{y}, A_{z}\right)\right)^{\prime} \\
& \text { ここに, } \phi: \text { 静電ポテンシャル, } A: \text { ベクト } \\
& \text { ルポテンシャル }
\end{aligned}
$$

境界での波動関数をやはり〈3・1〉節と同じく( 1$)$ ， (2)，(4)式で与える。(5)式は磁界中では次のよう に変更される。

$$
\begin{aligned}
\Psi(\vec{r})= & -\frac{\hbar}{2 m^{*}} \int_{S} d \vec{S}^{\prime}\left[G^{A}\left(\vec{r}, \vec{r}^{\prime}\right)\right. \\
& \times\left\{\vec{\nabla}^{\prime}-i \frac{e}{\hbar} \vec{A}\left(r^{\prime}\right)\right\} \Psi\left(\overrightarrow{r^{\prime}}\right)-\Psi\left(\vec{r}^{\prime}\right) \\
& \left.\times\left\{\vec{\nabla}^{\prime}+i \frac{e}{\hbar} \vec{A}\left(r^{\prime}\right)\right\} G^{A}\left(\vec{r}, \vec{r}^{\prime}\right)\right]
\end{aligned}
$$

しかし，〈3・1〉節と同樣に Diriclet 問題であるので， グリーン関数は境界上で

$$
G^{A}\left(\vec{r}, \vec{r}^{\prime}\right)=0 \quad\left(r^{\prime}: S \text { 上 }\right)
$$

\footnotetext{
*3シリース゚に接続したボイントコンタクト間ではサイクロトロ ン運動力生しない強さの橪界在印加している。従って, この近 似が使える程度の印加䣄界でる。
}

電学論 $\mathrm{C}, 110$ 巻 12 号, 平成 2 年

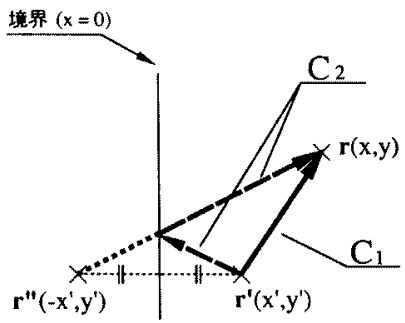

図 11 弱磁界中でのグリーン関数在求めるた めのべクトルポテンシャルについての積分回路 Fig. 11. Integral path to calculate the Green's function in weak magnetic field.

を満たす（以後， $G^{A, D}$ と記す)。従って，(31)式は

$$
\Psi(\vec{r})=\frac{\hbar}{2 m^{*}} \int_{S} d \overrightarrow{S^{\prime}} \cdot \Psi\left(\vec{r}^{\prime}\right) \vec{D}^{\prime} G^{A, D}\left(\vec{r}, \vec{r}^{\prime}\right)
$$

となる。

境界がある場合にも，弱磁界中のグリーン関数は (28)，(29)式と同様に，磁界がないときのグリーン関 数にベクトルポテンシャルの線積分で決まる位相因子 をかけて近似的に求めることができる。ただし，（i） 積分経路の終点に扔いて，積分経路はべクトルポテン シャルがないときにおけるグリーン関数の傾きの方向 と一致する必要がある。(ii)グリーン関数の相反性

$$
\begin{aligned}
& G^{A, D}\left(\vec{r}, \overrightarrow{r^{\prime}} ; \vec{A}(\vec{r})\right) \\
& \quad=G^{A, D}\left(\overrightarrow{r^{\prime}}, \vec{r} ;-\vec{A}\left(\overrightarrow{r^{\prime}}\right)\right)
\end{aligned}
$$

を渾たすために，グリーン関数の始点と終点を交換し たとき，積分回路が等しく（積分の方向㹥逆に）なら なければならない。

これらの条件を満たすものとして、図 11 に示す積 分経路を直接波と反射波について各々採用する。この ときのグリーン関数を以下に示す。

$$
\begin{aligned}
G^{A, D}\left(\vec{r}, \overrightarrow{r^{\prime}}\right) \\
=\exp \left(i \frac{e}{\hbar} \varphi_{1}\left(\vec{r}, \vec{r}^{\prime}\right)\right) G^{0}\left(x, y ; x^{\prime}, y^{\prime}\right) \\
\quad-\exp \left(i \frac{e}{\hbar} \varphi_{2}\left(\vec{r}, \vec{r}^{\prime}\right)\right) G^{0}\left(x, y ;-x^{\prime}, y^{\prime}\right)
\end{aligned}
$$

このとき，図 8 の鏡像に相当する部分は図 11 に抢け る反射に対応する。これらは印加磁界がないとき(ベ クトルポテンシャルがないとき）には完全に同等であ る。(35) 式の第 1 項は直接波によるもので，

$$
\varphi_{1}=\sum_{j=1}^{3} \int_{C_{1}} d \xi^{j} A_{j}(\xi)
$$

は $C_{1}$ の経路により生じた位相成分であり，第 2 項は 
反射波によるもので

$$
\varphi_{2}=\sum_{j=1}^{3} \int_{c_{2}} d \xi^{j} A_{j}(\xi)
$$

は $C_{2}$ の経路により生じた位相成分である。

また，実験においては $Z$ 方向に一榚磁界 $B$ が印加 されているので，Aを例光ば次のようにとればよい。

$$
A^{\mu}=(0,-B y, 0,0)
$$

このグリーン関数でポイントコンタクトの出ロから ディテクタの中心 $D(X, 0)$ まで 1 st モード[(1)式 $]$ と 2 nd モード〔(2)式〕を伝搬させると, 1 stモード の強度は $D$ 上で

$$
\left|\Psi_{1}^{A}(X, B)\right|^{2}=\left|\Psi_{1}(X, B)\right|^{2}+\left|\eta_{1}(X, B)\right|^{2}
$$

2nd ードの強度は

$$
\left|\Psi_{2}^{A}(X, B)\right|^{2}=\left|\Psi_{2}(X, B)\right|^{2}+\left|\eta_{2}(X, B)\right|^{2}
$$

となる。

ここで, $\left|\Psi_{1}(X, B)\right|^{2}$ おび $\left|\Psi_{2}(X, B)\right|^{2}$ はそれぞれ $\langle 3 \cdot 1\rangle$ 節で磁界を古典的に取扱って求めた (12) 式执よ び(13)式の第 2 項と同じものである（ただし， $R=$ $X)$ 。また $\left|\eta_{1}(X, B)\right|^{2},\left|\eta_{2}(X, B)\right|^{2}$ は直接波と反射波 との位相差から生じるものであり，以下に示す。

$$
\begin{aligned}
\left|\eta_{1}\right|^{2}= & \frac{4}{\pi k_{F}} \frac{1}{X L} 16\left(\frac{e B}{2 \hbar}\right)^{2} \\
& \times\left[\frac{\pi \cos \left(\frac{e B X L}{4 \hbar}\right)}{-\left(\frac{e B X}{2 \hbar}\right)^{2}+\left(\frac{\pi}{L}\right)^{2}}\right. \\
& \left.-\frac{4 \frac{e B X}{2 \hbar} \frac{\pi}{L} \sin \left(\frac{e B X L}{4 \hbar}\right)}{\left\{-\left(\frac{e B X}{2 \hbar}\right)^{2}+\left(\frac{\pi}{L}\right)^{2}\right\}^{2}}\right]^{2} \\
\left|\eta_{2}\right|^{2}= & \frac{4}{\pi k_{F}} \frac{1}{X L} 16\left(\frac{e B}{2 \hbar}\right)^{2} \\
& \times\left[\frac{2 \pi \cos \left(\frac{e B X L}{4 \hbar}\right)}{-\left(\frac{e B X}{2 \hbar}\right)^{2}+\left(\frac{2 \pi}{L}\right)^{2}}\right. \\
& \left.-\frac{4 \frac{e B X}{2 \hbar} \frac{2 \pi}{L} \sin \left(\frac{e B X L}{4 \hbar}\right)}{\left\{-\left(\frac{e B X}{2 \hbar}\right)^{2}+\left(\frac{2 \pi}{L}\right)^{2}\right\}^{2}}\right]^{2}
\end{aligned}
$$

著者らの奏験条件の場合には，1 st モード．2 nd モードに対してそれぞれ，ピーク比でおよそ

$$
\left.\begin{array}{l}
\left|\Psi_{1}\right|^{2} \approx 100\left|\eta_{1}\right|^{2} \\
\left|\Psi_{2}\right|^{2} \approx 20\left|\eta_{2}\right|^{2}
\end{array}\right\}
$$

となる。よって, 著者らの実験条件 $(L \ll X<サ イ ク$ ロトロン直径）に扔いては，直接波と反射波の位相差
に起因する $\left|\eta_{1}\right|^{2}$ およひ $\left|\eta_{2}\right|^{2}$ は実験結果に影響を与え ない大きさとなる。従って，測定にかかる強度はポイ ントコンタクトでのモード数が 1 のとき,

$$
\left|\Psi_{1}^{A}(X, B)\right|^{2} \cong\left|\Psi_{1}(X, B)\right|^{2}
$$

モード数が 2 のとき,

$$
\left|\Psi^{A}(X, B)\right|^{2} \cong\left|\Psi_{1}(X, B)\right|^{2}+\left|\Psi_{2}(X, B)\right|^{2}
$$

で磁界を古典的に扱った場合と近似的に一致する*4。 (44)，(45) 式の場合も, やはりフラウンホーファー回 折であるが，回折を生じさせる位相差を作り出すもの は，ク゚リーン関数にも現れている電子波の伝搬経路上 のベクトルポテンシャルの存在である。

一方，〈3・1〉節の解析（零磁界でスクリーン上での 電子強度を求めた解析）もフラウンホーファー回折で あるが，その回折を起こすための位相差は電子の伝搬 経路の行路差が原因である。

しかし，(12），(13)式と(44)，(45)式から，行路差 によるフラウンホーファー回折像がローレンツカでず れたとする（磁界の取扱いに関して古典的な）解析結 果と, ベクトルポテンシャルの存在による位相変化か ら生じたフラウンホーファー回折という（磁界の取扱 いに関して量子力学から出発した）解析結果が一致し たことがわかる。その結果として，この夷験の場合に 扮ける定常的な弱磁界の下では，磁界の取扱いに関し 古典的な見方が許される。従って，〈3・1〉節のスクり ーン上の回折像が磁界によって移動したという考え方 は妥当である。よって，これらの解析と実験結果のモ 一ド数 1 のときのシングルピーク．モード数 2 のとき のダブルピークの形状，およびダブルピークの磁界に 対する位置の一致から，これらの実験は確かにポイン トコンタクトの出射角分布を測定したものであり，そ の出射角分布は定在波的分布をもつ電子波のフラウン ホーファー回折で説明できる。

(44)，(45)式をプロットしたものも図10に示した ものである。また，以上の電子波の伝搬によって得ら れた計算結果と実験の一致から，著者らの実験結果は コヒーレントな電子波伝搬による回折・干涉効果によ って生じたものであると考えられる。

(参 考) ここでは，ポテンシャルの形状を井户 形としているが実際には放物形のほうが現実に近い。

*4 磁界が存在すると气に れるのて，必扎もく3・2〉節での姜論の上うに干涉項が消之る とは限らない。しかし、ここては弱磁界中てあり，柔の对称性

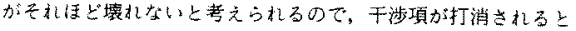
いつ傾向はを机ほど変化しないと思わ机る。っって、ニこでは 干涉坥を無視した。 
この場合でも同様な解析結果が得られることはたやす く推測できる。しかし，この場合の固有関数を伝搬さ せたときはサブピークは現れないこと（モード数 1 な ら中央のシングルピークのみ，モード数 2 ならダブル ピークのみ現れる）が大きな相違点である。

\section{4. むすび}

量子ポイントコンタクトからの電子の出射角分布の 測定において，ポイントコンタクトでのモード数によ って，角度分布が異なることを初めて見いだした ${ }^{(4)}$ c モード数 2 のときのダブルピークは特筆できる。ま た, この結果はポイントコンタクトで量子化された電 子波（定在波的分布をもつ電子波）のフラウンホーフ アー回折現象によって説明できることについて述 ベた。

今回, 特に磁界についての考察を弱磁界中で量子力 学から出発して行い, その結果としてこの実験の場合 の回折は電子波伝搬経路相互間の, ベクトルポテンシ ヤルによって生じる位相差によることがわかったが, 同時に磁界を古典的に扱った場合の，スクリーンに映 った回折像がローレンツカで移動したという考え方 は, 弱磁界においては妥当であることもわかった。従 って, 実験は確かに出射角分布を測定したものであ り，その結果はいず机にせよ定在波的分布をもつ電子 波のフラウンホーファー回折で説明できる。

更に, 1 st モード. 2 nd モード間の干渉は印加磁界 がないときに，実際には観測にかからないことを入射 波および系の対称性から示した。

本研究を行うにあたり, 大学・民間共同研究（メン スコピック・エレクトロニクス」文部省大型基礎プロ ジェクトの一環として有益な御助言をいただきました 東京大学生産研生駒俊明教授, 東京大学物性研安藤 恒也教授に感謝いたします。また，磁界中でのキルヒ ホッフーホイヘンスの定理の表(31) 式について御助言 をいただきました慶応大学理工学部川村 清教授に 感謝いたします。また，御協力いただいた $\mathrm{EB}$ 露光グ ループ石割秀敏氏, 小瀬村欣司郎氏, 永田武雄氏, および結晶成長グループ藤井俊夫氏, 佐々誠彦氏, 中田義昭氏に感謝いたします。日ごろ御指導いただい ている柴富昭洋氏に感謝いたします。

(平成 2 年 6 月 26 日受付, 同 2 年 10 月 23 日再受付)

$$
\text { 文献 }
$$

(1) B. J. van Wees, H. van Houten, C. W. J. Beenakker, J. G. Willamson. L. P. Kouwenhoven. D. van der Marel \& C. T. Foxon: "Quantized Conductance of Point Contacts in Two-Dimensional Electron Gas". Phiss. Ret: Lett. 60, 848

電学論C, 110 巻 12 号, 平成 2 年
(1988)

(2) D. A. Wharam, T. J. Thornton. R. Newbury, M. Pepper, H Ahmed. J. E. F. Frost, D. G. Hasko, D. C. Peacock, D. A Ritchie \& G. A. C. Jones: "One-dimensional transport and the quantization of the ballistic resistance", J. Phys. C21 L 209 (1988

(3) L. W. Molenkamp, A, A. M. Staring, C. W. J. Beenakker. R. Eppenga, C. E. Timmering, J. G. Willamson, C. J. P. M. Harmans \& C. T. Foxson: "Electron-Beam collimation with a quantum point contact". Phys. Rev. B41, 1274 (1990)

（4）离藤・岡田・小瀬村・永田・石割・横山：「开子ポイントコ ンタクトから発射される電子波の角度分布」, 信学技報, ED90-4, 21 (平 2) : M. Okada, M. Saito, M. Takatsu. K Kosemuru, T. Nagata, H. Ishiwari \& N. Yokoyama "Angular Distribution of Electros Injected through a Quantum Point Control" to be publisheoa in Superlattices and Microstructures

(5) B. J. van Wees, L. P. Kouwenhouven, H. van Houten, C. W J. Beenakker, J. E. Mooji. C. T. Foxson \& J. J. Harris "Quantized conductance of magnetoelectric subbands in ballistic point contacts", Phys, Rev., B38, 3625 (1988)

(6) Julian Schwinger, "Particles, Sources, and Fields", Vol. II, p. 21 (1973) Addison-Wesley

(7) L. P. Gor'kov: "Microscopic Derivation of The Ginzuburg.Landu Equations in The Theory of Superconductivity", Soviet Phys. JETP9. 1364 (1959)

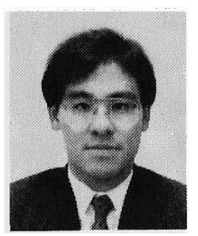

\section{褱 藤 美 寿 (正員)}

昭和 62 年東京工業大学理学部物 理学科卒業。平成元年同修士課程修 了。同年富士通研究所入社。以来, 量子効果デバイスの研究に従事。現 在, 同社機能デバイス研究部第二研究室所属。物理学 会会員。

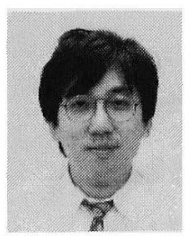

岡田誠(非会員)

昭和 61 年早稲田大学大学院修士 課程修了。同年富士通研究所入社。 以来, 量子細線など, 量子効果デバ イスの研究に従事。現在, 同社機能 デバイス研究部第二研究室所属。応用物理学会会員。

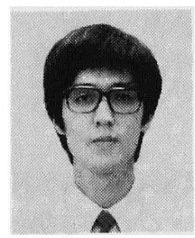

\section{高 津求 (非会員)}

昭和 62 年東京大学大学院博士課 程修了。同年富土通研究所入社。以来, 共鳴トンネルのウィグナー形式によ る過渡解析, 共鳴トンネリングホッ トエレクトロントランジスタの論理回路など, 量子効 果デバイスの研究に従事。現在, 同社機能デバイス研 究部第二研究室所属。工学博士。応用物理学会会員。 


\section{横 山 直 樹 (非会員)}

昭和 46 年大阪市立大学理学部物 理学科卒業。 48 年大阪大学大学院 修士課程修了。同年富士通研究所入 社。以来, 化合物半導体デバイスの
研究に従事。現在, 同社機能デバイス研究部第二研究 室長。工学博士。1987 年 GaAs Symposium Young Scientist Award, 学術奖励賞受賞。応用物理学会会 員, 電子情報通信学会, IEEE, AIP 会員。 